\title{
GEOPHYSICAL AND GEOCHEMICAL EVIDENCE FOR COLD UPPER MANTLE BENEATH THE EQUATORIAL ATLANTIC OCEAN
}

\author{
Susanna Eleonora Sichel ${ }^{1}$, Sonia Esperança ${ }^{2}$, Akihisa Motoki ${ }^{3}$, Marcia Maia ${ }^{4}$, \\ Mary F. Horan ${ }^{5}$, Peter Szatmari ${ }^{6}$, Eliane da Costa Alves ${ }^{7}$ and Sidney L.M. Mello ${ }^{8}$ \\ Recebido em 14 setembro, 2007 / Aceito em 24 janeiro, 2008 \\ Received on September 14, 2007 / Accepted on January 24, 2008
}

\begin{abstract}
This paper presents geophysical and geochemical evidence for the possible existence of cold, subducted lithosphere beneath the Saint Paul Fracture Zone of the Equatorial Atlantic Ocean. The ocean floor along the fracture zone is characterized by a high percentage of abyssal peridotites. The abyssal peridotites were emplaced by tectonic uplift of the oceanic lithosphere. The top of the ridge is exposed at Saint Peter and Saint Paul islets. The 0s isotopic composition of these abyssal peridotites indicate the presence of old depleted mantle material in this region with Re-depletion model ages ( $\mathrm{T}_{\mathrm{RD}}$ ) from 0.32 to 1.1 Ga. Melt inclusions in plagioclase phenocrysts of the MORB close to this location have boninitic composition, suggesting that some basalts originated from low-degree mantle melting. The global tomography models show fast seismic velocities in the upper and lower mantle of the Equatorial Atlantic Ocean, consistent with the presence of cold subducted lithosphere. The range of Re-depletion model ages are consistent with paleo-reconstructions of plate motion, suggesting that the fossil subducted slab was formed during the closure of both the lapetus and the Rheic oceans.
\end{abstract}

Keywords: Equatorial Atlantic Ocean, Saint Paul Fracture Zone, abyssal mantle, Re-Os isotope system, cold mantle, fossil subducted slab.

RESUMO. 0 presente trabalho mostra evidências geofísicas e geoquímicas para a possível existência de fragmentos frios do manto originados da placa subductada abaixo da Zona de Fratura de São Paulo no Oceano Atlântico Equatorial. A planície abissal desta área é caracterizada por uma abundância de rochas peridotíticas, com presença de poucas rochas basálticas originadas de baixo grau de fusão parcial. Arquipélago de São Pedro e São Paulo se localiza no topo de uma elevação morfológica com mais de $4000 \mathrm{~m}$ de altura, constituída por peridotitos abissais, posicionados por um soerguimento tectônico da litosfera oceânica. A razão isotópica de Os dos peridotitos da Zona de Fratura de São Paulo indica a presença de materiais originados de antigo manto depletado nesta região com as idades modelo de 0.32 a 1.1 Ga. As inclusões de magma trapeadas nos fenocristais de plagioclásio nos basalto da cadeia meso-oceânica pouco mais ao sul apresentam composição boninítica, típicas de zona de arco. Os modelos da tomografia mundial do manto demonstram alta velocidade sísmica tanto no manto superior quanto no inferior do Oceano Atlântico Equatorial, o que corrobora a interpretação da presença de placa subductada de baixa temperatura. As idades do modelo de depleção de Re dos peridotitos são consistentes com a reconstituição de movimento das placas, sugerindo que os fragmentos de placa fóssil subductada são provenientes do fechamento tanto do Oceano lapetus como o do Oceano Rheic.

Palavras-chave: Oceano Atlântico Equatorial, Zona de Fratura de São Paulo, manto abissal, sistema isotópico Re-Os, manto frio, placa fóssil subductada.

\footnotetext{
${ }^{1}$ Departamento de Geologia, LAGEMAR, Universidade Federal Fluminense, Brazil. E-mail: susanna@igeo.uff.br

2 Division of Earth Sciences, National Science Foundation, Arlington, VA 22230, USA. E-mail: sesperan@nsf.gov

${ }^{3}$ Departamento de Mineralogia e Petrologia Ígnea, Universidade do Estado do Rio de Janeiro, Brazil. E-mail: amotoki@pesquisador.cnpq.br

${ }^{4}$ CNRS, UMR 6538 Domaines Océaniques, IUEM, Plouzané, France. E-mail: marcia@univ-brest.fr

${ }^{5}$ DTM-CIW, 5241 Broad Branch Rd, Washington DC, USA. E-mail: mhoran@ciw.edu

${ }^{6}$ CENPES-PETROBRAS, Brazil. E-mail: szatmari@petrobras.com.br

${ }^{7}$ Departamento de Geologia, LAGEMAR, Universidade Federal Fluminense, Brazil. E-mail: eliane@igeo.uff.br

${ }^{8}$ Departamento de Geologia, LAGEMAR, Universidade Federal Fluminense, Brazil. E-mail: sidney@igeo.uff.br
} 


\section{INTRODUCTION}

Lateral variations in the temperature of the Earth's mantle have significant influence on the morphological and structural characteristics of mid-oceanic ridges. Hotspots, such as Iceland and Azores, induce excess axial morphologic elevation, with high magma production and consequently thickened crust. On the other hand, transform fault zones represent morphological depressions, with low magma production, and thin oceanic crust (Schilling et al., 1995; Thibaud et al., 1998). In some localities, serpentinized mantle peridotite is exposed directly on the abyssal surface, forming elliptic hills called "megamullion" (Tucholke et al., 1998, 2001; Ohara et al., 2001). These areas, so-called "cold spots", or "cold zones", are less common and little understood in comparison with hotspots. The best-known case is the Australian-Antarctic Discordance, called AAD, which probably reflects the presence of the cold, subducted lithosphere in the mantle (Gurnis et al., 1998; Ritzwoller et al., 2003), also called "megalith" (Fukao et al., 1994; Maruyama, 1994). A second probable cold spot lies in the equatorial region of the Atlantic Ocean.

The primary evidence for the presence of cold upper mantle beneath the Equatorial Mid-Atlantic Ridge comes from the structural analysis of the ridge axis morphology and the petrology of both basaltic and peridotitic rocks dredged from the area (Fig. 1; Gorini, 1981; Bonatti \& Honnorez, 1970; Bonatti, 1990; Bonatti et al., 1993; Schilling et al., 1995). Deep axial domains are usually associated with colder mantle temperature, generally along the length of the transform fault. For example, the Australian-Antarctic Discordance is characterized by a depth anomaly of about 800 meters (Christie et al., 1998). In the Equatorial Atlantic Ocean, the deepest point is located at southern part of the Saint Paul transform fault fracture zone (Schilling et al., 1995), with depth anomaly of about $700 \mathrm{~m}$. The basalt samples from the Equatorial Mid-Atlantic Ridge have different compositions from other parts of the mid-oceanic ridge system, and show a notable enrichment of incompatible elements. This phenomenon is attributed to melt enrichment derived from low degree of partial melts from a deeper but relatively colder upper mantle. Schilling et al. (1995) estimated that the temperature of this region may be 100 to $150^{\circ} \mathrm{C}$ lower than other areas of normal Mid-Atlantic Ridge.

The geometry of the ridge axis at the Equatorial Mid-Atlantic Ridge is marked by one of the largest offsets of the whole Atlantic Ocean (Fig. 1). Cold barrier effects of the exceptionally long transform faults (Fox \& Gallo, 1984) could be partially responsible for the low mantle temperature and consequent low melting rates. However, this factor is not enough to explain the entire re- duction in temperature observed (Bonatti et al., 1993; Schilling et al., 1995). Moreover, numerical modelling suggests that the cold barrier effect is localized, extending only a few kilometres away from the ridge-transform intersection (Schilling et al., 1995).

Two models for the formation of the cold upper mantle have been suggested. Bonatti (1990) proposed the possible existence of downwelling of mantle flow in a broad area of the Equatorial Atlantic region. The cold mantle mass could have originated from sub-continental lithospheric blocks entrained in the upper mantle during the continental rifting of West-Gondwana and subsequent formation of the Atlantic Ocean. In an alternative model, Schilling et al. (1995) attributed the cold mantle to an accumulation of subducted oceanic lithosphere at the margin of the lapetus and Rheic Oceans from the time of Pangea formation.

In order to constrain further the origin of the cold mantle of Equatorial Atlantic zone, this study combines geochemical and geophysical data of the area around Saint Paul transform fault fracture zone.

\section{GEOCHEMISTRY OF THE ABYSSAL PERIDOTITE}

A suite of samples was collected from a large area around the Saint Paul Fracture Zone during a deep sea diving survey using the scientific submersible Nautile (Hekinian et al., 2000). Ten abyssal peridotitic rocks and one of basaltic dyke sample were selected for the analyses of major elements, trace elements (Table 1), including Re, Pt, and Os contents, and Os isotopic ratios (Table 2). The chemical analyses were performed at CNRS-Université de Bretagne Occidentale, France, following the protocol described in Cotten et al. (1995).

Samples for this study were collected in 7 of the 13 dives along the intra-transform ridges (Fig. 2), and from the North and the South Ridges of the Saint Peter Saint Paul massif. This massif is about $90 \mathrm{~km}$ long and $21 \mathrm{~km}$ wide at the $3000 \mathrm{~m}$ depth contour line, composed of two E-W trending ridges, called, respectively, North Ridge and South Ridge, forming an "S" shaped morphologic high (Hekinian et al., 2000). The highest point is on the North Ridge, exposing its top above the sea level as small islands. They are called officially by the Brazilian Government "Arquipélago de São Pedro e São Paulo".

Some parts of Saint Peter Saint Paul North Ridge crop out above sea level forming 5 islets (Fig. 3). This is the only locality in which serpentinized mantle peridotite of megamullion (Motoki et al., 2008). Because of the alteration problem, the samples were selected based on freshness. They were analysed with high priority because they have highest contents of 0 s and 


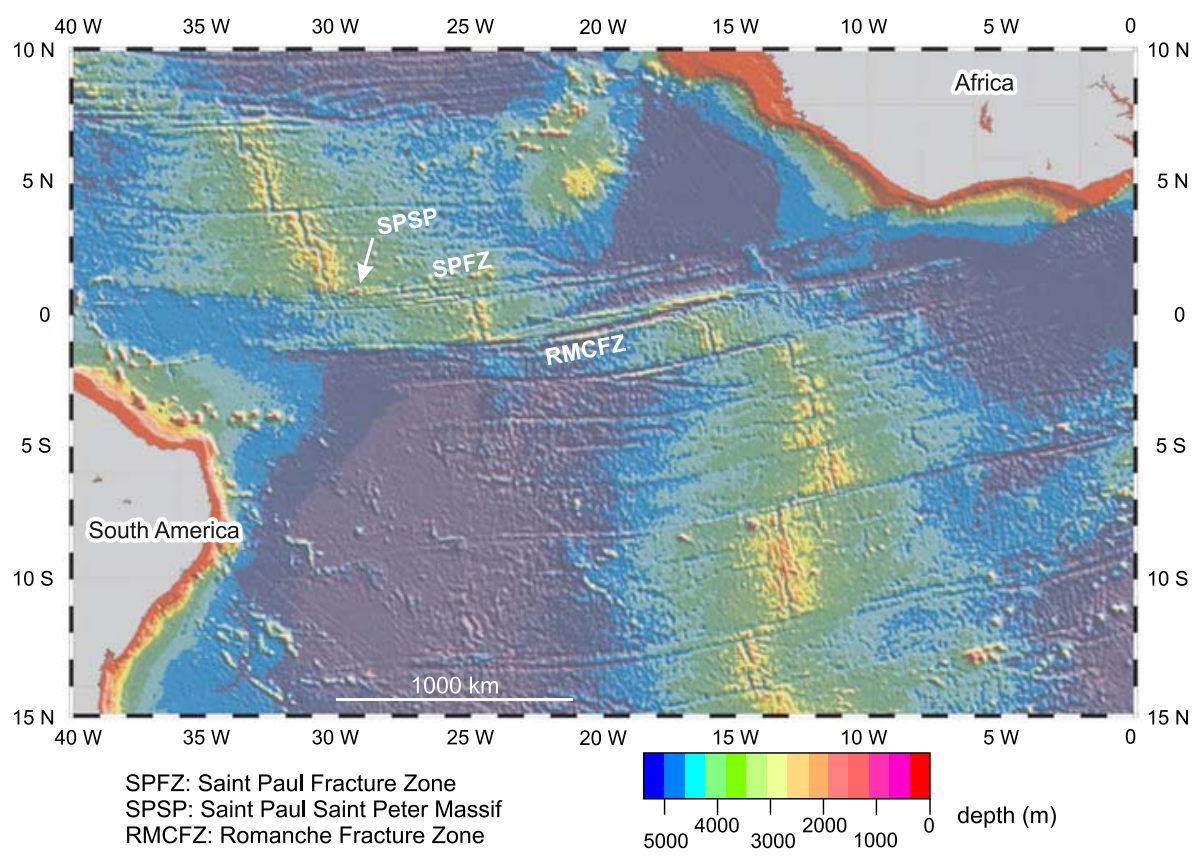

Figure 1 - Satellite predicted bathymetry (Smith \& Sandwell, 1997) of the mid-oceanic ridge in Equatorial Atlantic region.

are best situated to present the mantle-derived residual material than may yield geochemical information regarding the underlying mantle evolution. Os is highly compatible in mantle assemblages and has a notable contrast with Re partitions into the melt. Episodes of mantle melting therefore, slow or stop the ingrowths of radiogenic ${ }^{187}$ Os over time, and allow the Re-Os isotope system to be used to constrain the depletion history of the mantle (Shirey \& Walker, 1998).

Determination of reliable geochemical information of the abyssal peridotite is not easy because of seawater alteration and serpentinization, hydrothermal fluid interaction at high and low temperatures, and potential contamination by ocean floor sediment. The major element composition indicates high loss-onignition (Table 1), as expected from the intensity of serpentinization. Snow \& Dick (1995) showed that some major elements, such as $\mathrm{Mg}$, can be removed during alteration on the seafloor. Mével (2003) stated that the serpentinization has little effect on most elements except for $\mathrm{CaO}$, and that the $\mathrm{MgO}$ loss would take place only in low temperature weathering conditions of less than $100^{\circ} \mathrm{C}$.

Figure 4 shows $\mathrm{Re}, \mathrm{Os}$, and $\mathrm{Pt}$ variations with $\mathrm{MgO}$ contents. The Re and Os abundances have almost no correlation to $\mathrm{MgO}$, although Re addition during the serpentinization or hydrothermal alteration is possible. It is unlikely that these processes would add Os to the mantle peridotite. Likewise, the Pt contents ap- pear to have no correlation with $\mathrm{MgO}$, indicating that $\mathrm{Pt}$ is also little influenced by seafloor alteration. The peridotite samples have high $\mathrm{MgO}$ concentrations that are not clearly correlated with $\mathrm{CaO}$, which is a highly mobile element during alteration. These observations indicate that the major element composition of these peridotite samples was not significantly affected by serpentinization or hydrothermal alteration even at low temperature. Therefore, the major and trace element variations may reflect directly the chemical characteristics of the oceanic mantle. For instance, the samples of Saint Paul Fracture Zone have lower $\mathrm{Al}_{2} \mathrm{O}_{3}$ and $\mathrm{CaO}$ contents than the peridotitic rocks of the Kane Fracture Zone. These differences in major element composition are possibly a reflection of oceanic mantle chemical heterogeneities between above-mentioned areas.

It is noteworthy that sample SP 06-01 has low $\mathrm{SiO}_{2}$ and $\mathrm{MgO}$, but high $\mathrm{Al}_{2} \mathrm{O}_{3}$ and $\mathrm{FeO}$. This sample was extracted from a dyke and possibly represents a vein formed by the interaction of melts or fluids derived from peridotite in the oceanic lithosphere. This interpretation is consistent with high $\mathrm{Ti}, \mathrm{V}$ and $\mathrm{Sc}$ contents, low $\mathrm{Cr}$ and $\mathrm{Ni}$, and less radiogenic $\mathrm{Os}$ isotopic ratio of this sample (Tables 1-2). Therefore, this sample is excluded from the diagrams for peridotite samples.

An inverse correlation between 0 s and $\mathrm{Al}_{2} \mathrm{O}_{3}$ contents is generally observed in residual phases of melting events. Figure 5 shows variations of Re, Os, Pt contents, and of ${ }^{187} \mathrm{Re} /{ }^{188} \mathrm{Os}$ and 
Table 1 - Bulk rock composition of the Saint Paul Fracture Zone samples. XRF analyses have been performed at Université de Bretagne Occidentale, Brest, France. Major elements are expressed in weight \% and trace elements in ppm.

\begin{tabular}{|c|c|c|c|c|c|c|c|c|c|c|c|c|}
\hline & $\mathrm{SiO}_{2}$ & $\mathrm{TiO}_{2}$ & $\mathrm{Al}_{2} \mathrm{O}_{3}$ & $\mathrm{Fe}_{2} \mathrm{O}_{3}$ & $\mathrm{MnO}$ & $\mathrm{MgO}$ & $\mathrm{CaO}$ & $\mathrm{Na}_{2} \mathrm{O}$ & $\mathrm{K}_{2} \mathrm{O}$ & $\mathrm{P}_{2} \mathrm{O}$ & L. 0. I & Total \\
\hline SP 03-06 & 38.4 & 0.02 & 1.10 & 8.40 & 0.11 & 38.0 & 0.30 & 0.14 & 0.01 & 0.02 & 13.31 & 99.81 \\
\hline SP 04-01 & 39.7 & 0.03 & 1.20 & 7.70 & 0.09 & 37.2 & 0.07 & 0.09 & 0.03 & 0.01 & 13.33 & 99.45 \\
\hline SP 08-02 & 37.9 & 0.03 & 1.03 & 8.40 & 0.10 & 39.3 & 0.66 & 0.06 & 0.00 & 0.01 & 12.01 & 99.45 \\
\hline SP 09-01 & 41.7 & 0.12 & 2.54 & 8.60 & 0.13 & 35.8 & 1.32 & 0.19 & 0.38 & 0.05 & 8.28 & 99.11 \\
\hline SP 09-02 & 37.2 & 0.08 & 1.27 & 9.47 & 0.10 & 37.1 & 0.61 & 0.07 & 0.05 & 0.03 & 13.38 & 99.36 \\
\hline SP 12-08 & 36.6 & 0.04 & 0.81 & 8.49 & 0.45 & 36.3 & 0.10 & 0.16 & 0.02 & 0.05 & 16.25 & 99.27 \\
\hline SP 12-10 & 37.3 & 0.03 & 1.47 & 8.33 & 0.31 & 36.5 & 0.40 & 0.22 & 0.02 & 0.04 & 14.81 & 99.43 \\
\hline SP $12-12$ & 39.1 & 0.02 & 1.44 & 8.07 & 0.09 & 36.8 & 0.46 & 0.14 & 0.02 & 0.03 & 13.31 & 99.48 \\
\hline SP 12-16 & 38.4 & 0.06 & 1.33 & 8.08 & 0.15 & 37.4 & 0.45 & 0.07 & 0.01 & 0.02 & 13.45 & 99.37 \\
\hline SP 13-13 & 38.4 & 0.02 & 1.25 & 7.55 & 0.11 & 35.8 & 1.68 & 0.12 & 0.01 & 0.02 & 14.00 & 98.96 \\
\hline \multirow[t]{2}{*}{ SP 06-01 } & 27.5 & 1.11 & 19.72 & 19.8 & 0.14 & 20.6 & 0.67 & 0.13 & 0.01 & 0.18 & 9.95 & 99.76 \\
\hline & $\mathrm{Rb}$ & Sr & $\mathrm{Ba}$ & Sc & V & $\mathrm{Cr}$ & Co & $\mathrm{Ni}$ & Y & $\mathrm{Zr}$ & $\mathrm{Nb}$ & \\
\hline SP 03-06 & 0.15 & 10 & b.d. & 8.2 & 50 & 1600 & 100 & 2100 & 0.5 & 2 & 0.2 & \\
\hline SP 04-01 & 0.5 & 5 & b.d. & 7.6 & 34 & 1350 & 101 & 2150 & 0.7 & 2 & 0.1 & \\
\hline SP 08-02 & 0.3 & 9 & 10 & 7.5 & 35 & 2560 & 110 & 2200 & 0.3 & 3 & 0.1 & \\
\hline SP 09-01 & 12.5 & 48 & 88 & 8.8 & 45 & 2460 & 90 & 1900 & 2.5 & 6 & 10 & \\
\hline SP 09-02 & 2 & 60 & 35 & 6.4 & 42 & 2245 & 95 & 1785 & 1.5 & 3 & 2.4 & \\
\hline SP 12-08 & 0.3 & 14 & 24 & 7.4 & 76 & 1630 & 195 & 2200 & 1.2 & 11 & 1.2 & \\
\hline SP 12-10 & 0.2 & 14 & 8 & 9.8 & 76 & 1980 & 156 & 1960 & 2.4 & 10 & 0.8 & \\
\hline SP 12-12 & 0.3 & 5 & 4 & 9.4 & 65 & 2015 & 84 & 2000 & 0.6 & 3 & 0.2 & \\
\hline SP 12-16 & 0.25 & 7 & 4 & 9.8 & 57 & 2275 & 104 & 2075 & 1.3 & 4 & 0.3 & \\
\hline SP 13-13 & 0.15 & 34 & 2 & 9.7 & 53 & 2150 & 100 & 2160 & 0.7 & 3 & 0.2 & \\
\hline \multirow[t]{2}{*}{ SP 06-01 } & 0.45 & 10 & 7 & 39 & 250 & 345 & 106 & 255 & 12 & 54 & 1.9 & \\
\hline & La & $\mathrm{Ce}$ & $\mathrm{Nd}$ & Sm & $\mathrm{Eu}$ & $\mathrm{Gd}$ & Dy & $\mathrm{Er}$ & $\mathrm{Yb}$ & & & \\
\hline SP 09-01 & 5.3 & 10 & 3.8 & 0.85 & 0.25 & 0.5 & 0.4 & 0.25 & 0.26 & & & \\
\hline SP 09-02 & 2.4 & 3.5 & 1.3 & 0.7 & 0.17 & 0.2 & 0.25 & 0.15 & 0.18 & & & \\
\hline SP 12-08 & 1.2 & 10 & 1.5 & 0.45 & 0.1 & 0.2 & 0.3 & 0.15 & 0.17 & & & \\
\hline SP 12-10 & 2.2 & 10 & 2.5 & 0.7 & 0.11 & 0.3 & 0.45 & 0.3 & 0.31 & & & \\
\hline SP 12-16 & 0.7 & 2.2 & 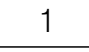 & 0.3 & 0.1 & 0 & 0.2 & 0.15 & 0.17 & & & \\
\hline SP 06-01 & 2.6 & 8.7 & 8.3 & 2.5 & 0.38 & 2.35 & 3 & 1.9 & 2.42 & & & \\
\hline
\end{tabular}

${ }^{187} \mathrm{OS} /{ }^{188} \mathrm{Os}$ with $\mathrm{Al}_{2} \mathrm{O}_{3}$ (wt\%). The absence of clear correlation between the platinum group elements and a melt-depletion proxy, such as $\mathrm{Al}_{2} \mathrm{O}_{3}$, indicates that the peridotite samples are not the result of a single melt-depletion event. The highest Os concentrations of the Saint Paul peridotites are projected on the range of the abyssal peridotites of the Kane Fracture Zone (Brandon et al., 2000). These values are reasonable for a depleted mantle source.

Many samples of the Saint Paul Fracture Zone have lower Re and Os but similar Pt contents than those of the Kane Fracture
Zone. One sample with a radiogenic Os isotopic ratio has high Pt, low 0s, and low Re contents (Fig. 6). The lower Os and Re contents of the Saint Paul Fracture Zone relative to the Kane Fracture Zone indicate distinct chemical characteristics of the oceanic mantle lithosphere between these fracture zones. The 0s isotopic variation of the Saint Paul Fracture Zone samples can be explained by the contamination of approximately 40 to $50 \%$ of sediments or infiltration of 30 to $40 \%$ of amphibolite veins (Fig. 6B). However, neither of these two models is consistent with the observed 
Table 2 - Re, Pt, and Os concentrations and Os isotopic ratio of the Saint Paul Fracture Zone samples. Re, Os concentrations and Os isotopic analysis have been performed at the IGL-Univ. of Maryland-College Park, according to the procedures of Meisel et al. (2001). Pt concentrations obtained by isotope dilution mass spectrometry at the Department of Terrestrial Magnetism, Carnegie Institution of Washington according to the procedures of Horan et al. (2003). The sample SP 06-01 is extracted from a dyke and the others are serpentinized peridotite.

\begin{tabular}{|l|c|c|c|c|c|c|c|c|c|}
\hline & Re (ppb) & Pt (ppb) & Os (ppb) & Pt/0s & ${ }^{187} \mathrm{Re} /{ }^{188}$ Os & ${ }^{187}$ OS/ $/{ }^{188}$ Os & error & $\gamma$ 0s & TRD (Ga) \\
\hline SP 03-06 & 0.027 & 9.13 & 3.11 & 2.94 & 0.042 & 0.12497 & 30 & -1.6 & 0.31 \\
\hline SP 04-01 & 0.508 & 5.08 & 3.66 & 1.39 & 0.669 & 0.11988 & 300 & -5.6 & 1.10 \\
\hline SP 08-02 & 0.028 & 5.86 & 3.71 & 1.58 & 0.037 & 0.12464 & 21 & -1.9 & 0.35 \\
\hline SP 09-01 & 0.255 & 4.50 & 3.18 & 1.42 & 0.386 & 0.12333 & 27 & -2.9 & 0.55 \\
\hline SP 09-02 & 0.084 & 2.38 & 2.59 & 0.92 & 0.156 & 0.12118 & 27 & -4.6 & 0.87 \\
\hline SP 12-08 & 0.018 & 7.28 & 1.36 & 5.35 & 0.063 & 0.14804 & 70 & 17.8 & \\
\hline SP 12-10 & 0.038 & 8.61 & 2.31 & 3.73 & 0.079 & 0.13697 & 18 & 7.8 & \\
\hline SP 12-12 & 0.105 & 3.53 & 1.10 & 3.21 & 0.460 & 0.12629 & 28 & -0.6 & 0.11 \\
\hline SP 12-16 & 0.038 & 3.03 & 0.84 & 3.60 & 0.219 & 0.12756 & 29 & 0.4 & \\
\hline SP 13-13 & 0.085 & 8.11 & 2.83 & 2.87 & 0.146 & 0.12481 & 26 & -1.7 & 0.33 \\
\hline SP 06-01 & 0.111 & 0.36 & 0.04 & 8.96 & 13.257 & 0.12285 & 14 & -3.3 & 0.87 \\
\hline
\end{tabular}

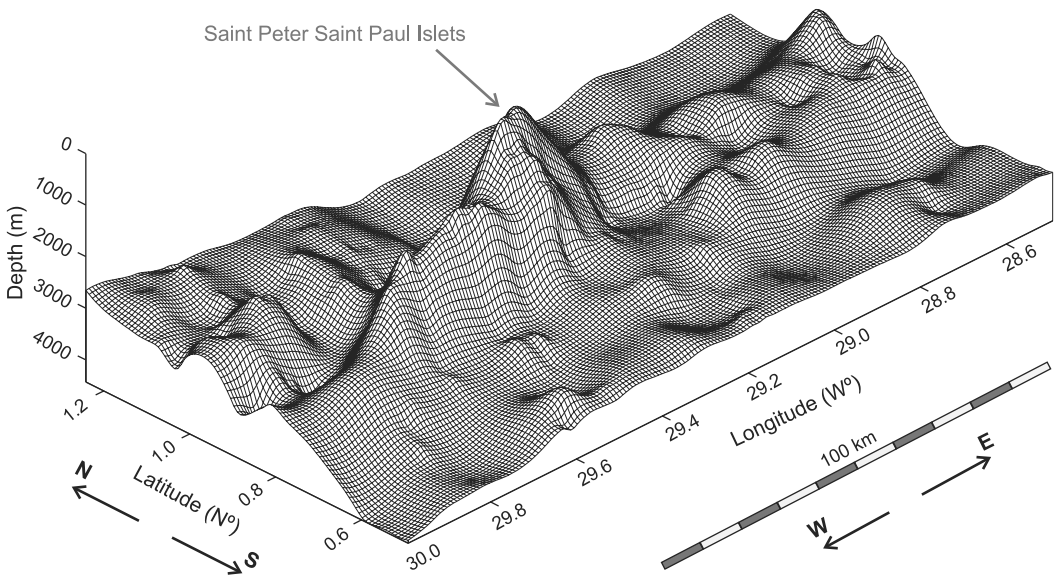

Saint Peter Saint Paul Megamullion
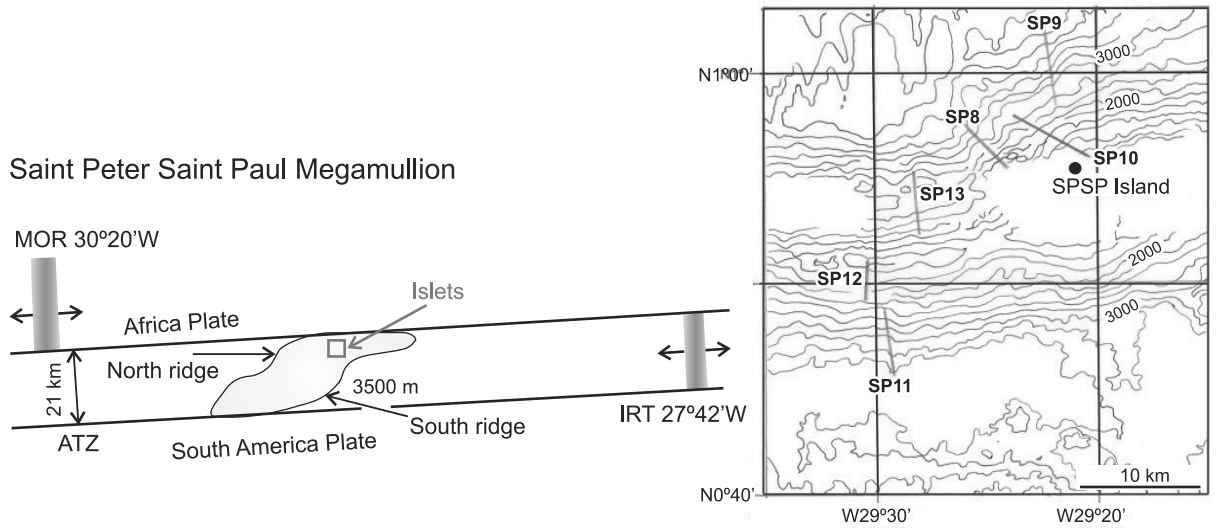

Figure 2 - Sigmoid ridge of Saint Peter Saint Paul at the Saint Paul Transform Fault with the location of the six dives, after Thompson (1981). The dives SP 8, SP 9 and SP 10 were in a tectonically deformed zone of the North flank. The dives Sp 11 and SP 12 were located in the undeformed peridotite zone of the South flank. The dive SP 13 was located in the ridge between the North and South flank. 




Figure 3 - Panoramic view from a helicopter of the Saint Peter Saint Paul Massif, Equatorial Atlantic region, after SECIRM (Secretaria da Comissão Interministerial para Recursos do Mar), Brazilian Navy Force.

low Re contents of the peridotite samples, because sediments and amphibolite are typically enriched in Re relative to mantle assemblages (Fig. 6C)

The same argument is valid for contamination of the peridotites by MORBs, as most basaltic melts also have high Re contents. In addition to the depletion in Os and Re contents, the end-member with radiogenic 0s isotopic composition has high Pt contents. The process that led to the depletion in Re and Os appears to be also capable of concentrating Pt. The radiogenic nature of this end member is a good indication that this mantle component is ancient. A study of mantle xenoliths from arc settings has shown that the oxidizing conditions of the mantle wedge above the subduction zones favors the removal of Re and 0 s from mantle assemblages (Brandon et al., 1996). Although it is not known how Pt would behave in similar conditions, it is possible that these chemical characteristics are inherited from an old subduction event.

The range of Os isotopic compositions obtained for this suite of rocks is large $\left({ }^{187} \mathrm{Os} /{ }^{188} \mathrm{Os}\right.$ saries from 0.11988 to 0.14804$)$ but the majority of the samples has $\gamma 0$ s values that are equal to or below chondritic values. These data cannot be explained simply by melt extraction from a fertile MORB mantle with homogeneous 0 s isotopic composition, and reinforce previous results by others indicating a sub-chondritic average for abyssal peridotites
(Martin, 1991; Roy-Barman \& Allègre, 1994; Snow \& Reisberg, 1995). The sub-chondritic Os isotopic composition of most of these peridotites also cannot be explained by interaction of the mantle assemblage with abyssal sediments that are significantly more radiogenic than the MORB mantle (Roy-Barman et al., 1998) or primitive upper mantle. Two peridotite samples have significantly higher 0 s concentrations and more radiogenic 0 s isotopic ratios. These characteristics could be attributed to possible assimilation of sediments and interaction of enriched melts or fluids (Fig. 7).

The chondritic to sub-chondritic Os isotopic composition of most Saint Paul Fracture Zone peridotites contrasts with models of Os isotopic evolution of the primitive upper mantle as constrained by spinel Iherzolites from continental environments that support a more chondritic value for the bulk upper mantle (Meisel et al., 1996, 2001). Model ages for Re-depletion for the sub-chondritic samples are in the range of $320 \mathrm{Ma}$ to $1,100 \mathrm{Ma}$, being classified into three groups:

1) Middle Proterozoic, about 1,100 Ma (SP 04-01, SP 1212);

2) Late Proterozoic, $870 \mathrm{Ma}$ (SP 09-02, SP 06-01); and

3) Carboniferous, $330 \mathrm{Ma}$ (SP 03-06, SP 08-02, SP 13-13). 
These ages might record depletion events of the abyssal peridotite and consequent old oceanic crust formation.
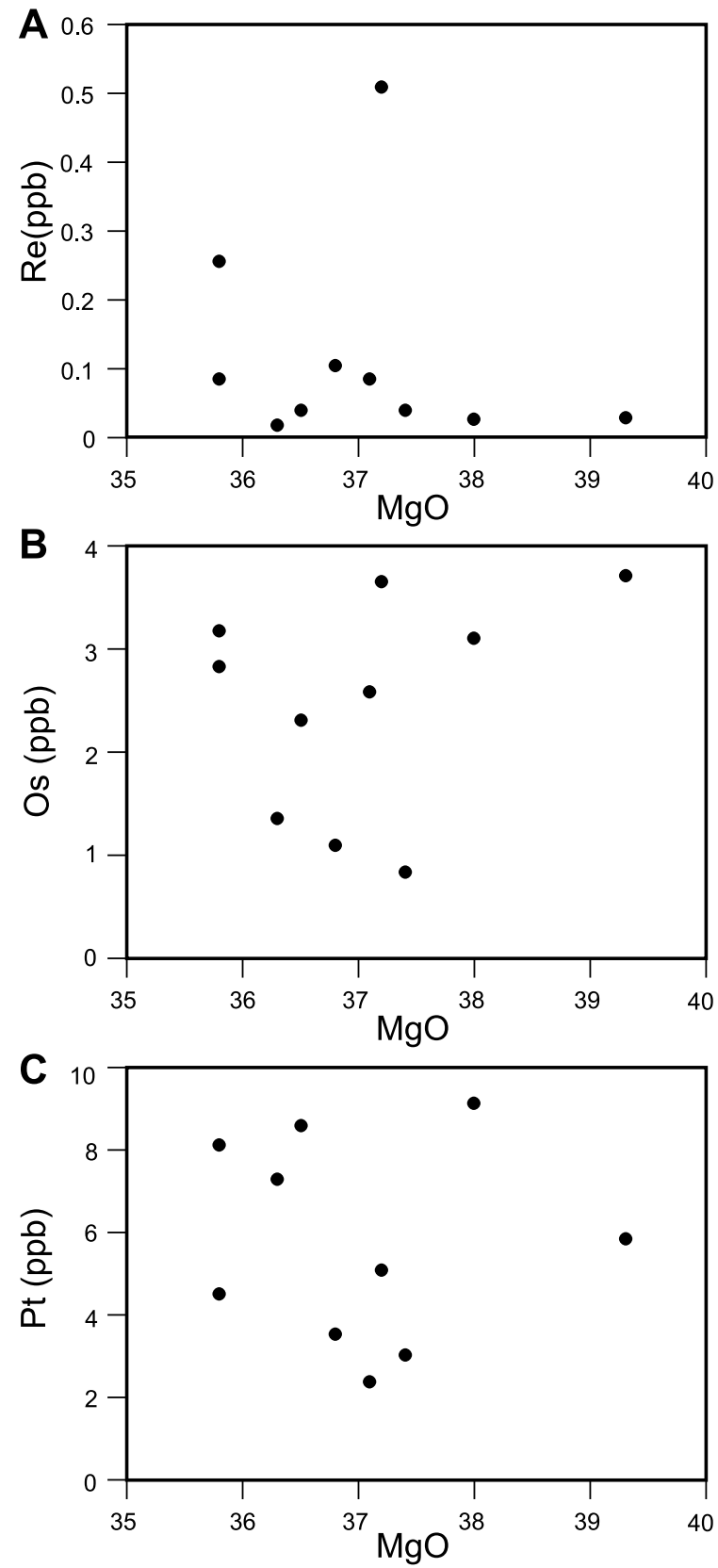

Figure 4 - Re, 0 s, and Pt contents versus $\mathrm{MgO}$ for the peridotite samples of the Saint Peter Fracture Zone of the present work.

This range of depletion model ages for the sampled mantle rocks is consistent with three different hypotheses:

1) Os isotopic composition of the MORB mantle is more unradiogenic than previously thought;

2) Abyssal peridotites entrained pieces of old continental lithosphere delaminated during the opening of the Atlantic Ocean; and

3) Abyssal peridotites inherited unradiogenic Os from depleted portions of fossil subducted slab, or megaliths.

The first hypothesis is less consistent with available data on chromite obtained from ophiolite sequences that have crystallised during oceanic lithosphere formation (Walker, 1989), and the limited but robust set of 0 s isotopic compositions of primitive basaltic rocks from oceanic environments (Lassiter \& Hauri, 1998). These data indicate that the MORB source, although somewhat heterogeneous, has probably a chondritic to slightly super-chondritic Os isotope ratio.

The second and third hypotheses can be supported by the ReOs isotopic composition presented. The sub-continental lithosphere along the Atlantic Ocean margins in the equatorial region is much older than Pan-African (1.1-0.9 Ga). However, the age of melt depletion related to the formation of oceanic lithosphere, and its subsequent subduction during the closing of the lapetus Sea in this region match better the Re-depletion model ages of the analysed peridotitic rocks.

The Os isotopic ratios of the Saint Paul Fracture Zone samples are not correlated with their ${ }^{187} \mathrm{Re} /{ }^{188} 0 \mathrm{~s}$ ratio and can be attributed to possible late Re mobilisation (Fig. 7). The data set shows a positive correlation between ${ }^{187} 0 \mathrm{~s} /{ }^{188} 0 \mathrm{~s}$ and $\mathrm{Pt} / \mathrm{Os}$ (Fig. 8). The same relationship was observed in the abyssal peridotites from Kane Fracture Zone (Brandon et al., 2000). In the Saint Paul Fracture Zone, Pt and Os concentrations also appear to be positively correlated, and the samples with higher Pt/0s ratios also have lower overall concentrations of these two platinum group elements.

\section{MELT INCLUSION OF BONINITIC COMPOSITIONS}

The composition of parental liquids to mid-ocean ridge basaltic rocks is controlled by source characteristics such as pressure, temperature, bulk mantle composition, degree of partial melting, and the presence of volatile species. Mid-ocean ridge primary magmas are generally basaltic and the freshest samples can be obtained from volcanic glass in abyssal pillow lavas that have cooled rapidly to prevent extensive fractionation, and are the best chemical proxies for their original source composition. The melt inclusions trapped within plagioclase phenocrysts in this glass can provide important information about their parental melt because they were isolated from later processes, such as magma mixing and crystallisation fractionation. However, their composition could be modified by post-entrapment recrystallisation of 

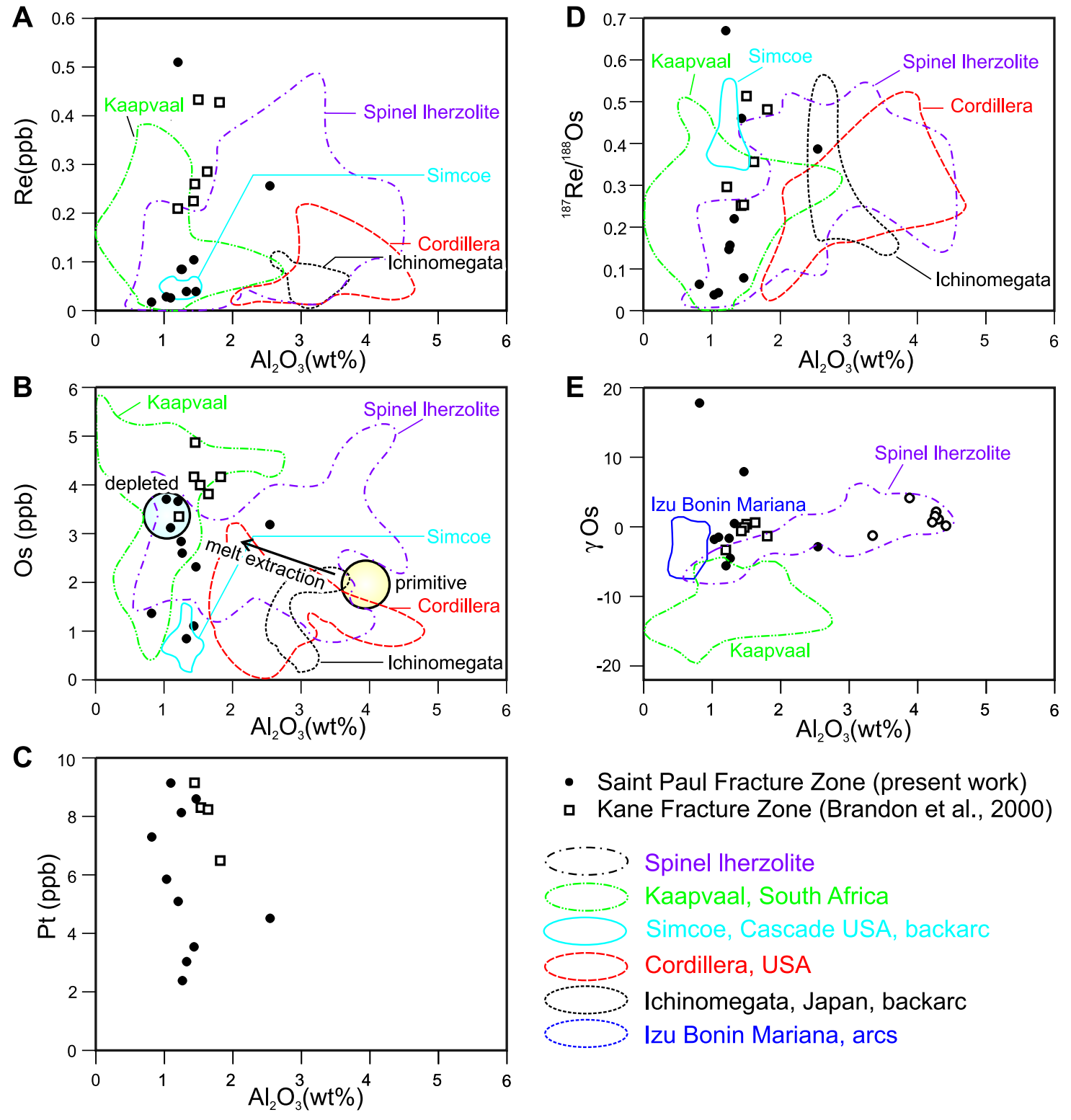

- Saint Paul Fracture Zone (present work)

- Kane Fracture Zone (Brandon et al., 2000)

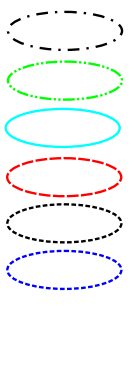

Spinel Iherzolite

Kaapvaal, South Africa

Simcoe, Cascade USA, backarc

Cordillera, USA

Ichinomegata, Japan, backarc

Izu Bonin Mariana, arcs

Figure 5 - Re, 0 s and Pt concentration contents, ${ }^{187} \mathrm{Re} /{ }^{188} 0 \mathrm{~s}$, and $\gamma 0$ s plotted against $\mathrm{Al}_{2} \mathrm{O}_{3}$ (wt\%). The distribution fields of ultramafic rocks from other regions are after a compilation by Carlson et al. (1999).

the host crystal, such as mineral growth. In order to evaluate the extent of host mineral crystallisation, it is important to note the relationship between the composition of the inclusion and the host mineral, zoning, or internal heterogeneity, which would provide a strong argument for the host mineral recrystallisation. Once host recrystallisation has been evaluated, the melt inclusion composition can be adjusted back to its original entrapment composition.

Sichel (1990) presented the analyses of the melt inclusions in plagioclase phenocrysts and their host minerals, obtai- ned from dredged samples of Mid-Atlantic Ridge (EN61-2D; latitude $2^{\circ} 24^{\prime} S$ ). A group of plagioclase crystals appears to be in equilibrium with the MORB matrix glass. However, the range in anorthite content for the plagioclase phenocrysts that contain melt inclusions goes up to $\mathrm{An}_{90}$, which can be interpreted as representing a more primitive melt composition than the matrix glass. The Mg\# (Mg/Mg+Fe) of these primitive melt inclusions are 6970. Table 3 shows major and trace element compositions of the matrix glass and representative melt inclusions. 


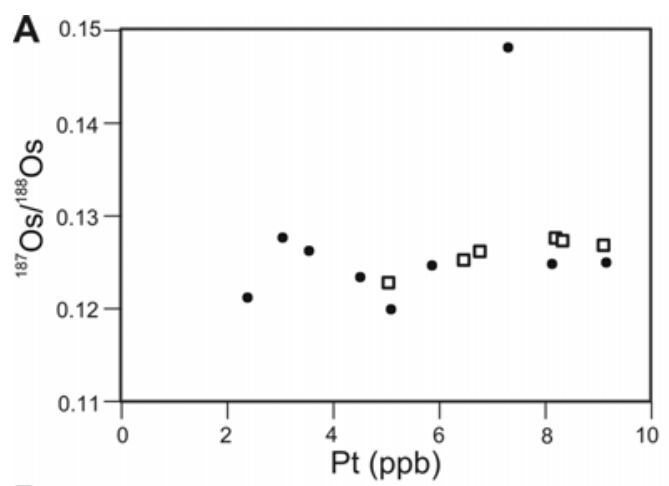

- Saint Paul Fracture Zone (present work)

- Kane Fracture Zone (Brandon et al., 2000)


Figure 6 - Comparative diagram of Pt, Os, and Re variations against ${ }^{187} 0 \mathrm{~s} /{ }^{188} \mathrm{Os}$ of the Saint Peter Fracture Zone and the Kane Fracture Zone. The diagram B shows mixing lines for MORB, sediments and amphibole.
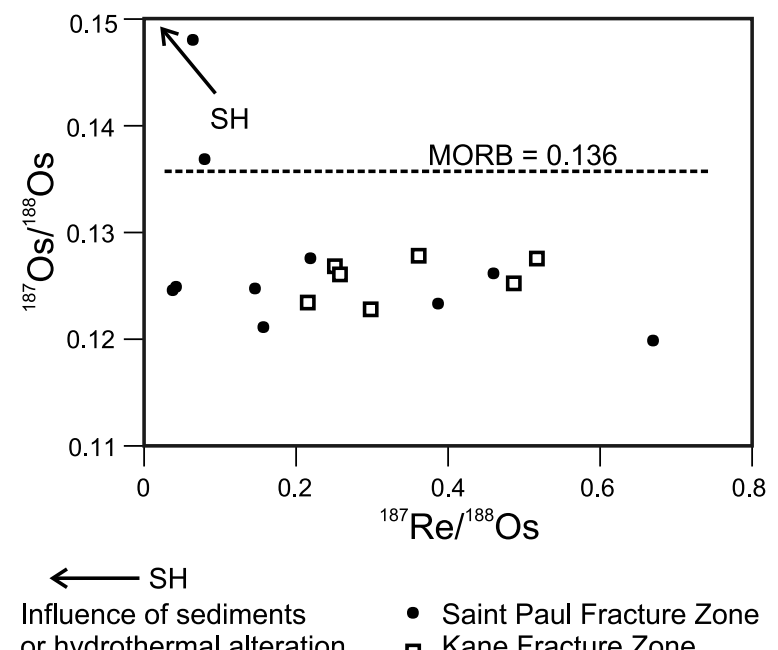

- Saint Paul Fracture Zone or hydrothermal alteration

- Kane Fracture Zone

Figure $7-{ }^{187} \mathrm{Re} /{ }^{188} 0$ s versus ${ }^{187} 0 \mathrm{~s} /{ }^{188} 0$ s diagram for the peridotite samples of the Saint Paul Fracture Zone of this work and of the Kane Fracture Zone (Brandon et al., 2000). The ${ }^{187} \mathrm{Os} /{ }^{188} 0$ s ratio for MORB is taken from Roy-Barman et al. (1998).

The high $\mathrm{MgO}$, high $\mathrm{SiO}_{2}$ and enriched LREE of the melt inclusions are consistent with a boninitic composition. Boninite is a primary high-magnesia andesitic magma generated from the partial melting of young and hot oceanic crust in the presence of $\mathrm{H}_{2} \mathrm{O}$, generally in subduction zones (Crawford et al., 1989; Tatsumi \& Maruyama, 1989). Such melting conditions are present only in certain localities of arcs in which ridge subduction takes place. The presence of melt inclusions of boninitic composition in pla- 

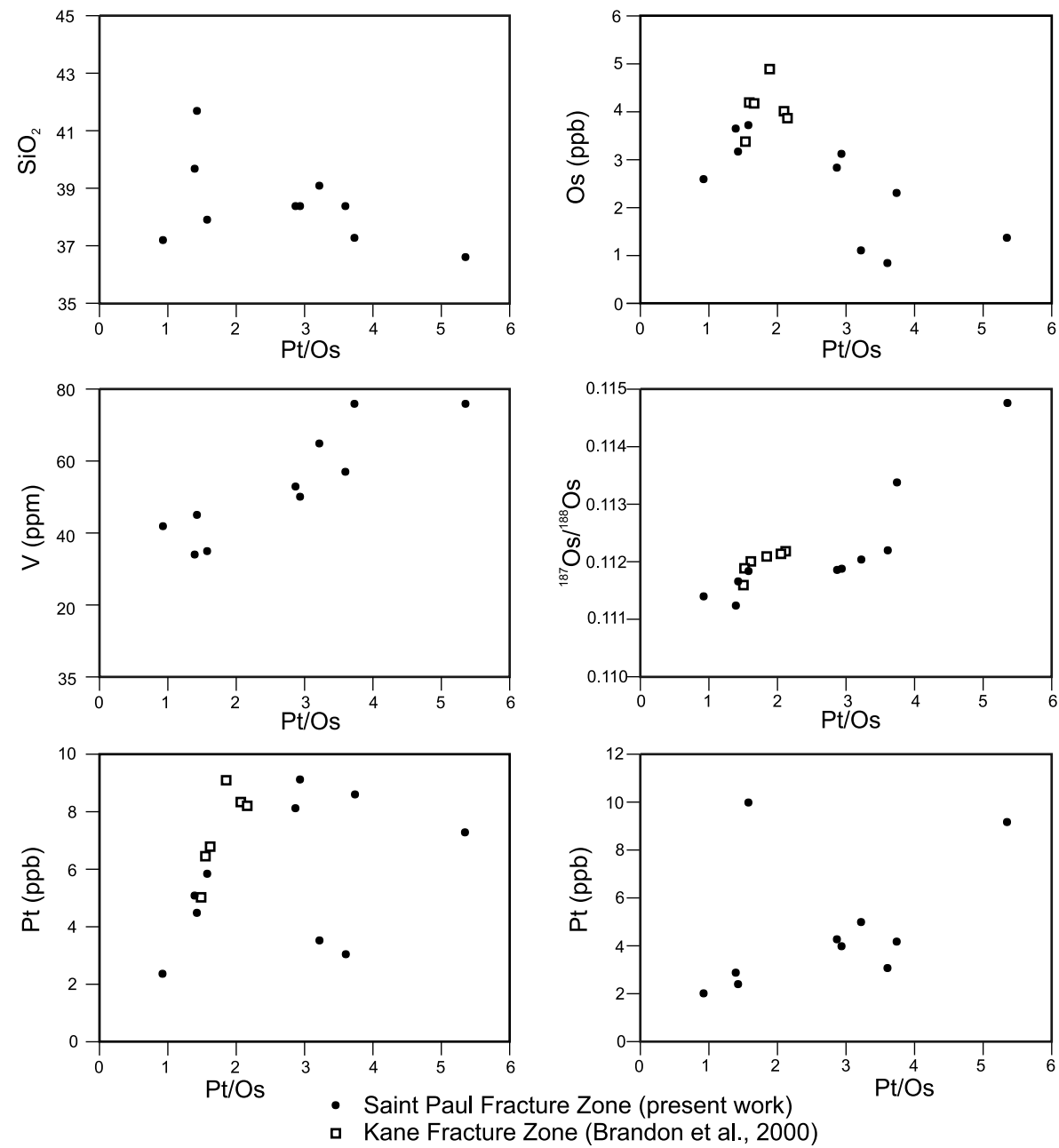

Figure 8 - $\mathrm{SiO}_{2}$ and trace elements versus Pt/Os composition of ultramafic rocks from Saint Paul Fracture Zone (present data) and from Kane Fracture Zone (Brandon et al., 2000).

gioclase phenocrysts in volcanic glasses from the Mid-Atlantic Ridge is consistent with melt contribution to MORBs from magmas generated from melting of slab material at depth.

\section{SEISMIC TOMOGRAPHY}

The topographic and mantle Bouguer anomaly (Fig. 9) sections across the Mid-Atlantic Ridge show a topographic low and a high Bouguer anomaly in the Equatorial Atlantic area in comparison with the other regions.

The attenuation $Q$ model for seismic waves (Romanowicz \& Gung, 2002; Gung \& Romanowicz, 2004) demonstrates high Q values around the Mid-Atlantic Ridge of this region, implying cooler than normal mantle temperatures (Fig. 10). This surface anomaly corresponds to a high-Q body located in the lower part of the upper mantle. Global whole mantle tomographic models
(Boschi \& Dziewonski, 1999; Ritsema \& Van Heijst, 2000; Becker \& Boschi, 2002) also show significantly high seismic velocities beneath the Equatorial Mid-Atlantic Ridge (Fig. 11).

Although global tomographic models have generally low resolution at the surface (half-wavelength of $\sim 1000 \mathrm{~km}$ ), both the $S$ and $P$ models show high velocities in the upper mantle near the equatorial area. A notable characteristic of these whole-mantle seismological models is that the high velocity zone observed for the upper mantle apparently continues into the lower mantle. A similar phenomenon is observed in the present day subduction zones. This geophysical evidence is consistent with the presence of fossil subducted slab fragments in the mantle.

High seismic velocities of the mantle in areas in which subduction is no longer active are attributed to the presence of old slab fragments (Steinberger, 2000). The cold slab pieces can con- 
Table 3 - Major elements (wt\%) composition of matrix glass by XRF and melt inclusions in plagioclase by EPMA, and trace element contents (ppm) by ion probe at the MIT for the MORB samples collected from Equatorial Mid-Atlantic Ridge.

\begin{tabular}{|c|c|c|c|c|}
\hline & $\begin{array}{c}\text { Matrix glass } \\
\text { EN61-2 }\end{array}$ & $\begin{array}{c}\text { Melt inclusion } \\
14\end{array}$ & $\begin{array}{c}\text { Melt inclusion } \\
4\end{array}$ & $\begin{array}{c}\text { Melt inclusion } \\
1\end{array}$ \\
\hline $\mathrm{SiO}_{2}$ & 51.30 & 50.49 & 52.57 & 51.92 \\
\hline $\mathrm{TiO}_{2}$ & 1.61 & 0.77 & 0.54 & 0.54 \\
\hline $\mathrm{Al}_{2} \mathrm{O}_{3}$ & 15.98 & 9.40 & 15.15 & 8.94 \\
\hline $\mathrm{Fe}_{2} \mathrm{O}_{3}$ & 0.63 & 0.77 & 0.60 & 0.82 \\
\hline $\mathrm{Fe} 0$ & 8.95 & 10.97 & 8.60 & 11.66 \\
\hline $\mathrm{MnO}$ & 0.00 & 0.03 & 0.00 & 0.04 \\
\hline $\mathrm{MgO}$ & 8.30 & 13.77 & 11.19 & 15.30 \\
\hline $\mathrm{CaO}$ & 11.30 & 11.76 & 11.51 & 11.73 \\
\hline $\mathrm{Na} 20$ & 2.85 & 0.21 & 0.34 & 0.24 \\
\hline $\mathrm{K} 20$ & 0.04 & 0.05 & 0.04 & 0.03 \\
\hline $\mathrm{P} 2 \mathrm{O}_{5}$ & 0.11 & 0.27 & 0.15 & 0.11 \\
\hline $\mathrm{Total}$ & 101.07 & 98.49 & 100.69 & 101.33 \\
\hline $\mathrm{MG \#}$ & 62 & 69 & 70 & 70 \\
\hline \hline $\mathrm{Sr}$ & 115.70 & 86.00 & 119.00 & 82.00 \\
\hline $\mathrm{Ti}$ & 8803 & 2252 & 6009 & 2269 \\
\hline $\mathrm{V}$ & 244 & 107 & 119 & 114 \\
\hline $\mathrm{Cr}$ & 215 & 314 & 315 & 371 \\
\hline $\mathrm{Rb}$ & 13.40 & 5.00 & 17.00 & 7.00 \\
\hline $\mathrm{Y}$ & 37.48 & 12.00 & 26.00 & 10.00 \\
\hline $\mathrm{Zr}$ & 95.50 & 10.00 & 32.00 & 10.00 \\
\hline $\mathrm{Nb}$ & 3.20 & 0 & 7.20 & 0.00 \\
\hline $\mathrm{Ba}$ & 9.10 & 3.00 & 48.00 & 10.00 \\
\hline $\mathrm{Ce}$ & 0.51 & 6.85 & 4.75 & 1.26 \\
\hline $\mathrm{Nd}$ & 0.95 & 5.50 & 4.71 & 1.41 \\
\hline $\mathrm{Sm}$ & 1.38 & 3.17 & 2.41 & 3.00 \\
\hline $\mathrm{Dy}$ & 1.00 & 1.00 & 1.00 & 1.00 \\
\hline $\mathrm{Er}$ & 1.06 & 0.62 & 0.82 & 1.59 \\
\hline $\mathrm{Yb}$ & 1.09 & 0.57 & 0.72 & 0.87 \\
\hline & & & & \\
\hline
\end{tabular}

$\mathrm{Fe} 0=$ FeOtotal ${ }^{*} 0.9407$

tribute to maintain the low temperature in upper mantle long after the end of subduction. This low mantle temperature could decrease the magma production at the ridge axis, resulting in thinner crust and thicker lithosphere. The cold upper mantle would result in a highly segmented ridge axis system at greater depth, as is observed in the Australian-Antarctic Discordance.

\section{KINEMATIC PALEO-RECONSTRUCTIONS}

The existence of plate fragments in the Equatorial Atlantic region may be related to the numerous episodes of subduction that oc- curred during the assembly of Pangea (Blakey, 2004; Scotese, 2004) that spanned more than 200 million years. Several convergent margins were active in this region since the Late Cambrian. The equatorial area may have corresponded to a region of subduction during two collision events of Gondwana and Laurentia: 1) prior to the closing of the lapetus Ocean (Fig. 12A) in the Ordovician, about $460 \mathrm{Ma}$; and 2) prior to closing of the Rheic Ocean (Fig. 12B), in the Carboniferous and Permian, about $300 \mathrm{Ma}$ (Dalziel, 1997). The Carboniferous Re-Os model ages of about $330 \mathrm{Ma}$ fit well the Rheic Ocean closure event. The present positions of these subduction zones relative to the South Ameri- 

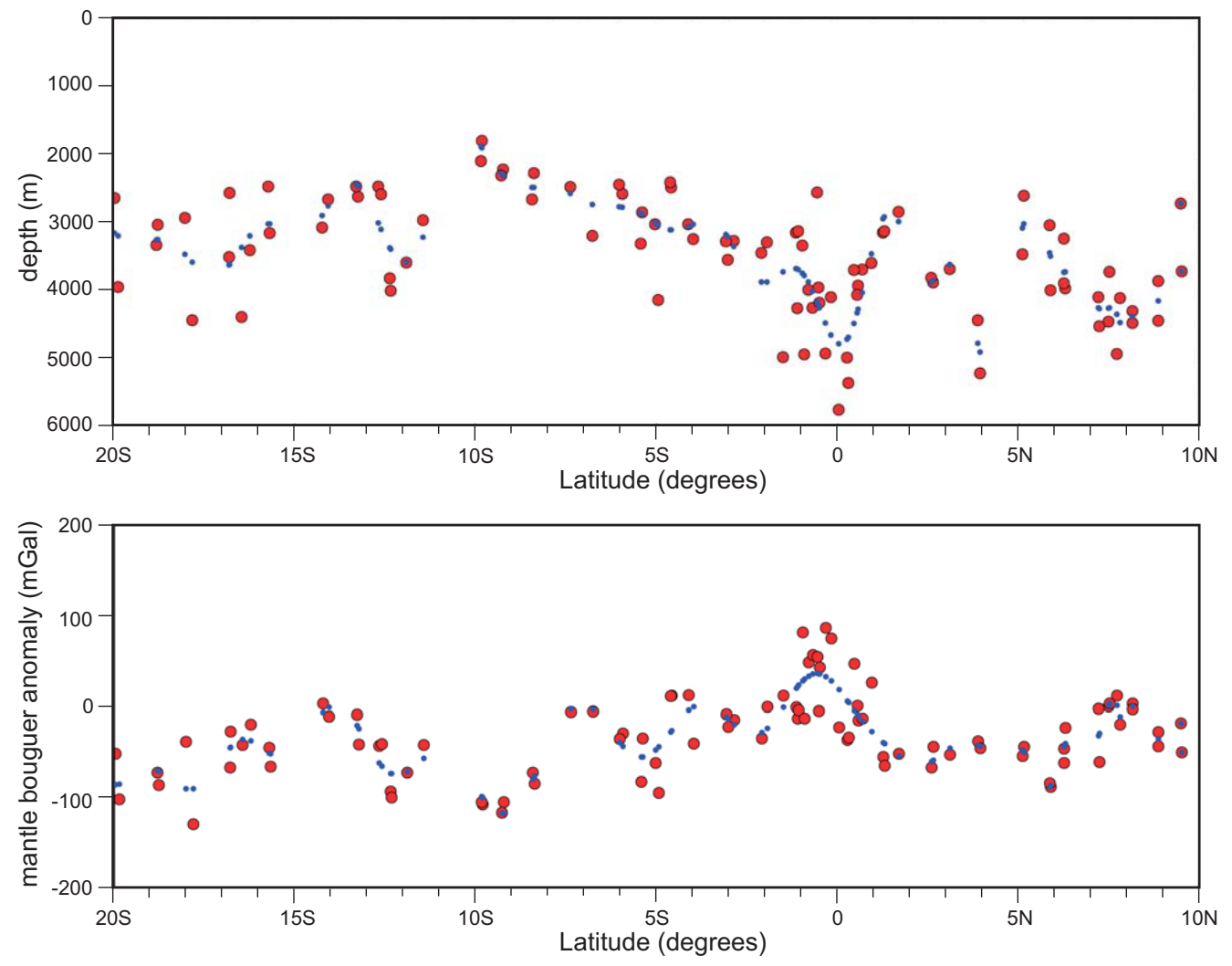

Figure 9 - Topographic (m) and Mantle Bouguer Anomaly (mGal) profile across the Mid-Atlantic Ridge. The red points represent bulk data and blue ones, best-fit model. Note the deepest depth and the highest MBA in the equatorial region.



Figure 10 - A vertical section of the Berkeley Q model (Gung \& Romanowicz, 2004) for the upper mantle along the axis of the Atlantic mid-oceanic ridge. Note the presence of sub-vertical high- $Q$ wall below the equatorial region.

can continental block are far from the present Equatorial Atlantic Ocean. If their positions are referenced relative to the fixed locations of hotspots, however, they are located in the present Equatorial Atlantic region. Therefore, convergent margins could have accumulated fossil slabs in the upper mantle below the present position of the Equatorial Atlantic Ocean.

Schilling et al. (1995) previously suggested that closing of the western block of Pangea prior to 300 Ma was a possi- 


\section{latitude $\left({ }^{\circ}\right)$}

latitude $\left({ }^{\circ}\right)$

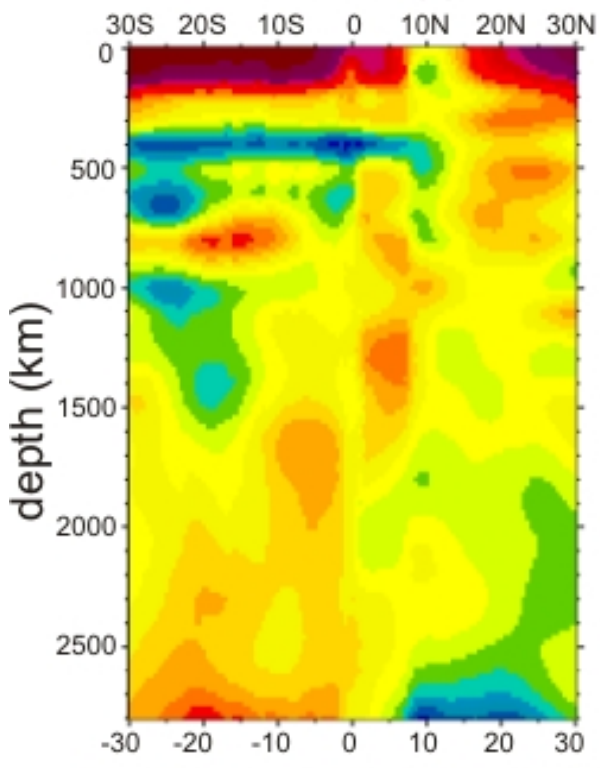

dVs: Ritsema \& Van Heijst (2000)
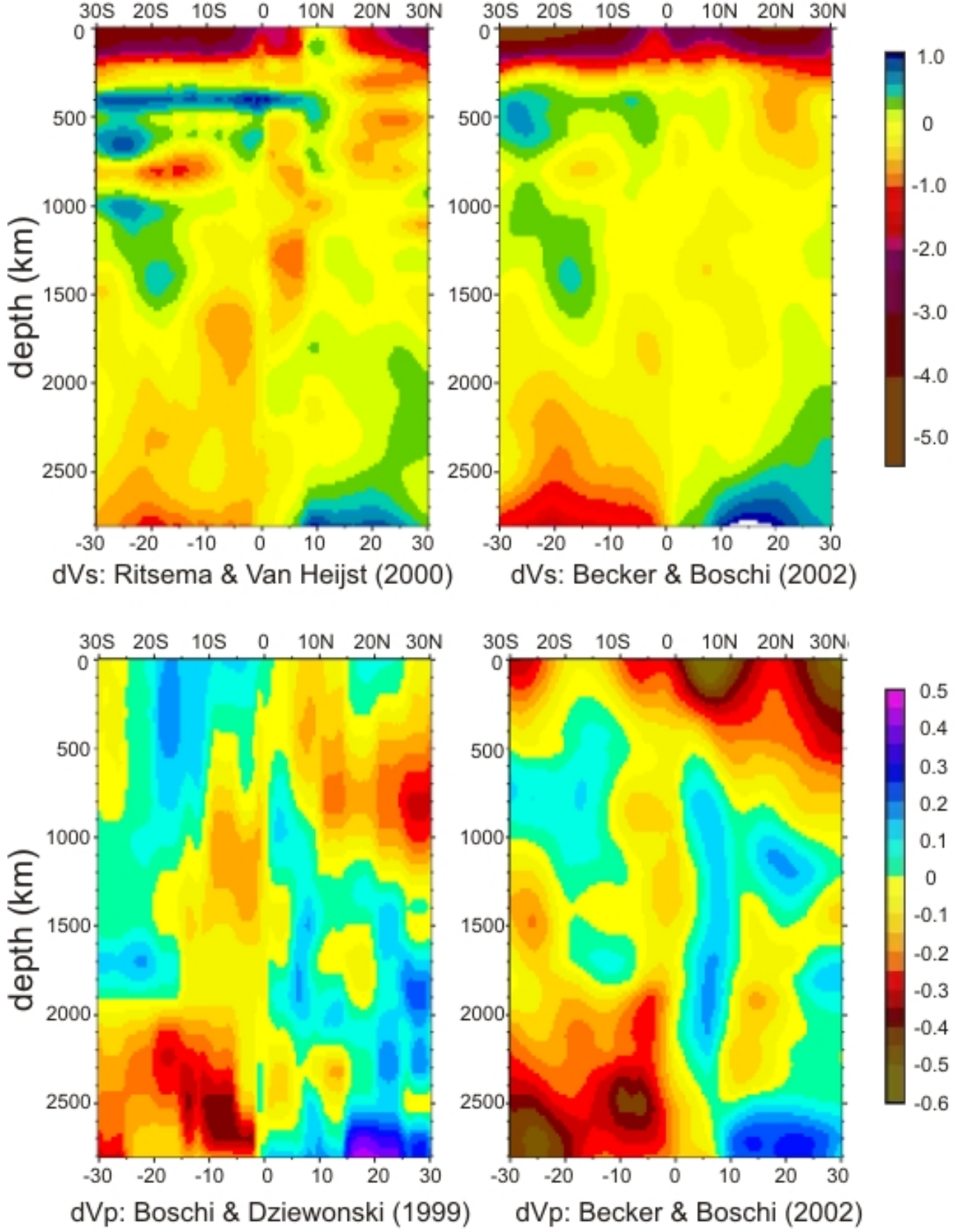

Figure 11 - Comparison between two whole mantle P and S models (Boschi \& Dziewonski, 1999; Ritsema \& Van Heijst, 2000) and the average P and S-wave models of Becker \& Boschi (2002). The average models enhance common and more stable features of different global tomographic models. Vertical sections are taken along the Mid-Atlantic Ridge axis.

ble origin for fragmentary blocks of oceanic lithosphere trapped in the upper mantle, which were remobilized upward during the subsequent rifting of Pangea and opening of the Atlantic Ocean (Fig. 13). An additional factor that could have contributed frag- ments of subducted lithosphere to the upper mantle is the shear movement that may have been active between Early and Late Permian along this margin of Pangea (Muttoni et al., 2003).

A similar process was proposed for the Australian-Antarctic 


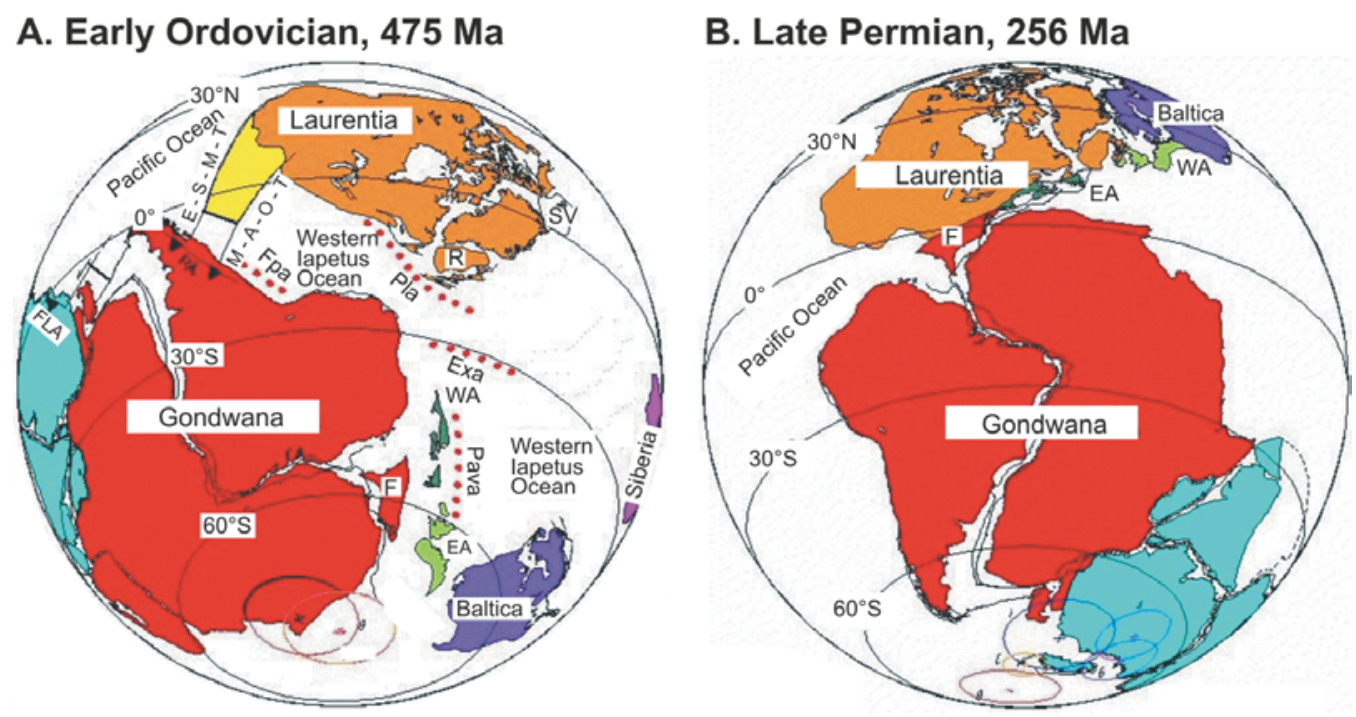

Figure 12 - Subduction zone positions relative to upper mantle after Dalziel (1997) for: A) lapetus Ocean at Chilean Patagonia; B) Rheic Ocean at western Africa, forming Pangea. The latitude is referred to hotspot position. Note that both subduction zones are situated in present Equatorial Atlantic region (latitude $0^{\circ}$ ).

\section{A. Subduction}

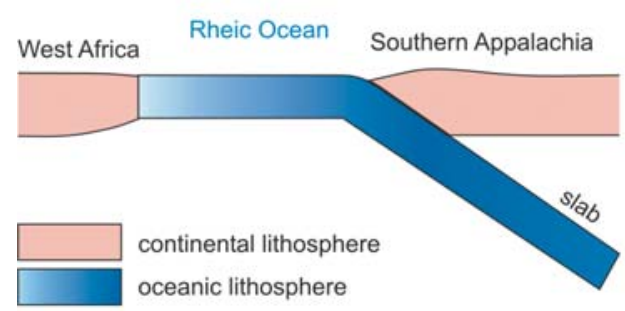

\section{Pangea formation}

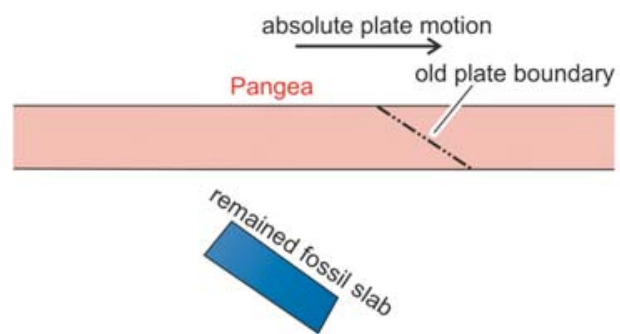

\section{B. Continental collision}

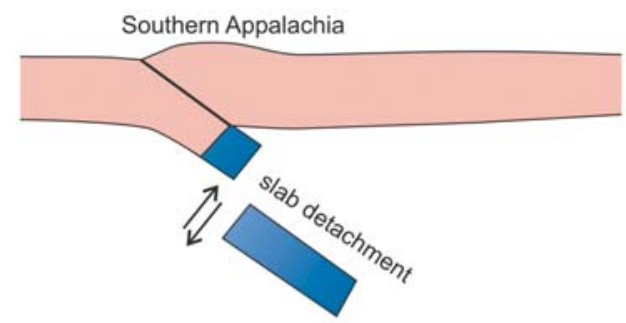

D. Equatorial Atlantic opening

Equatorial Atlantic Ocean Cold spot
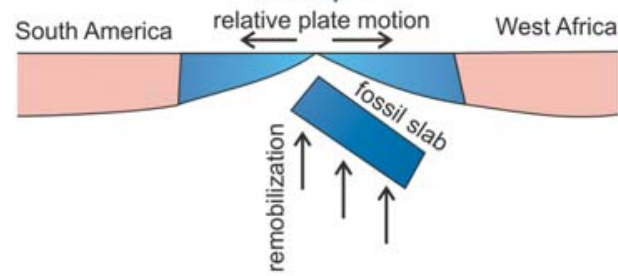

Figure 13 - Cartoons for the accumulation processes of cold lithospheric mantle fragments below the present position of the Equatorial Atlantic Ocean based on the plate movement model of Dalziel (1997): A) Rheic Ocean closing at the Early Permian; B) continental collision at the Late Permian; C) Pangea formation; D) Equatorial Atlantic Ocean opening and cold spot formation from the Early Cretaceous. The "absolute plate motion" of the illustration $\mathrm{C}$ corresponds to the plate movement relative to hotspots.

Discordance cold spot that, like the Equatorial Atlantic, has thin crust and a topographic low (Gurnis et al., 1998). The seismic tomography similarly revealed a high velocity anomaly in the mantle, interpreted as low mantle temperatures of this area that resulted from fragments of an ancient slab (Ritzwoller et al., 2003).
This slab is probably linked to a convergent margin that was active until about 100 million years ago. Although the AustralianAntarctic Discordance presents much stronger anomalies than the Equatorial Atlantic, we suggest that similar processes may have occurred in both areas. 


\section{DISCUSSION}

The Os isotopic ratios recorded in the abyssal peridotites, the degree of depletion of basalts and peridotites, the ridge axial morphology, and the high seismic mantle velocities support the existence of anomalous cold mantle material beneath the Equatorial Atlantic region. The Re depletion model ages and palaeo-reconstructions of the area both point to an event in the Palaeozoic, probably the closing of the lapetus Sea. Entrainment of subducted depleted mantle materials during the formation of the Atlantic oceanic lithosphere could have imparted the nonradiogenic Os signature to the abyssal peridotites in this region.

Further evidence of subducted components beneath the Equatorial Atlantic region comes from the trace element and isotopic composition of tholeiitic basalts from intra-transform ridges within the St. Paul Fracture Zone. These samples show elevated $\mathrm{Ce} / \mathrm{Pb}$ ratios, and ${ }^{87} \mathrm{Sr} /{ }^{86} \mathrm{Sr}$ isotopic ratios that plot towards the HIMU component of the oceanic array (Hemond et al., 2002), geochemical characteristics that are commonly interpreted to be inherited from ancient recycled oceanic crust.

The intense stretching of the lithosphere during the rifting and opening of the Equatorial Atlantic region might have induced delamination of the old continental lithosphere. The presence of cold continentally derived lithospheric fragments in the upper mantle could effectively reduce the average mantle temperature, thus yielding low melting rates and high seismic velocities at higher levels in the mantle. However, the high seismic velocities observed into the lower mantle in this region are more easily explained by the presence of a subducted slab than by delamination and downwelling of large blocks of subcontinental lithosphere.

It is speculated that the subduction at the margin of the Rheic Ocean until 300 million years ago provided the fossil slab mass around the present day position of the Equatorial Atlantic region relative to hotspots. Such cold slab material can be seen in a high velocity zone in the lower mantle on the tomographic image. Although the subducted lithosphere could have been created in a divergent period prior to 460 million years ago, the younger age estimates seem to be more consistent with the depletion model ages obtained with the Re-Os system.

\section{CONCLUSION}

Combined geochemistry on abyssal peridotites from the Saint Paul Fracture Zone, recent whole mantle tomographic models, and kinematic palaeo-reconstructions indicate that low mantle temperatures in the Equatorial Atlantic Ocean result from fragments of a subducted slab in the upper mantle. The presence of $\mathrm{Mg}-\mathrm{SiO}_{2}$ rich melt inclusions with LREE enrichment in MORB samples is consistent with the suggestion that the underlying oceanic mantle in the Equatorial Atlantic has chemical heterogeneities that are characteristic of those in arc settings. The colder lower mantle temperatures seen in global tomography models may have been induced by the detached cold slab fragments. These could also have the effect of cooling the upper mantle while maintaining a downwelling flow even without active present day subduction. Fragments of the subducted plate that were detached during earlier subduction could have melted or been entrained in the upper mantle, yielding the osmium isotopic compositions observed in the abyssal peridotites.

\section{ACKNOWLEDGEMENT}

The senior author is grateful to Roger Hekinian and Thierry Juteau for their mentorship and support during the cruise and to IFREMER for their support of the St. Paul Cruise of N/O Nadir and the Nautile. She also thanks Marcus Aguiar Gorini who offered her the unique opportunity for participating in the dives on the NAUTILE submersible in the St. Paul Transform Fault Zone. Richard Walker generously provided access to the Isotopic Geochemistry Laboratory of University of Maryland-College Park where the isotopic analyses were performed. This project received financial support of CAPES/COFECUB, program of the Brazilian Government (project 220/97 and 415/03); PETROBRAS/CENPES, Brazilian Petroleum Company (Project: Origem e Evolução das Rochas Mantélicas do Arquipélago de São Pedro e São Paulo); IUEM Université de Bretagne Occidentale, France; CNRS-INSU, France. The field trip to the island and chemical analyses were supported by the project Nos. 480023/2004-2 and 557309/2005-0 of the Brazilian Government, SECIRM/CNPq.

\section{REFERENCES}

BECKER TW \& BOSCHI L. 2002. A comparison of tomographic and geodynamic mantle models. Geochem. Geophys. Geosyst., 3(1): 1003, doi: 10.1029/2001GC000168

BLAKEY R. 2004. Paleogeography. Available at: <http://jan.ucc.nau.edu/ rcb7> > Access on: December 15, 2007.

BONATTI E. 1990. Subcontinental mantle exposed in the Atlantic Ocean on St. Peter-Paul islets. Nature, 345(6278): 800-802.

BONATTI E \& HONNOREZ J. 1970. Equatorial Mid-Atlantic Ridge: Petrologic and Sr Isotopic evidence for an Alpine-Type Rock Assemblage. Earth and Planetary Letters, 9: 247-256.

BONATTI E, SEYLER M \& SUSHEVSKAYA N. 1993. A Cold Suboceanic mantle belt at the Earth's Equator. Science, 261: 315-320. 
BOSCHI L \& DZIEWONSKI AM. 1999. High- and low-resolution images of the Earth's mantle - Implications of different approaches to tomographic modeling. J. Geophys. Res., 104(B11): 25,567-25,594.

BRANDON AD, CREASER RA, SHIREY SB \& CARLSON RW. 1996. Osmium recycling in subduction zones. Science, 272: 861-864.

BRANDON AD, SNOW JE, WALKER RJ, MORGAN JW \& MOCK TD. 2000. ${ }^{190} \mathrm{Pt}-{ }^{186} \mathrm{Os}$ and ${ }^{187} \mathrm{Re}^{-187}$ Os systematics of abyssal peridotites. Earth Planet. Sci. Lett. 177 : 319-335.

CARLSON RW, PEARSON DG, BOYD FR, SHIREY SB, IRVINE G, MENZIES AH \& GURNEY JJ. 1999. Re-Os systematics of lithospheric peridotites: Implications for lithosphere formation and preservation. In: GURNEY JJ, GURNEY JL, PASCOE MD \& RICHARDSON SH (Ed.). Proceedings of the $7^{\text {th }}$ International Kimberlite Conference. Red Roof Design C.C. Cape Town, South Africa. 99-107.

CHRISTIE DM, WEST BP, PYLE DG \& HANAN BB. 1998. Chaotic topography, mantle flow and mantle migration in the Australian-Antarctic discordance. Nature, 394: 637-644.

COTTEN J, LEDEZ A, BAU M, CAROFF M. MAURY RC, DULSKI P, FOURCADE S, BOHN M, \& BROUSSE R. 1995. Origin of anomalous rare-earth element and yttrium enrichments in subaerially exposed basalts: Evidence from French Polynesia. Chemical Geology, 119(1-4): 115-138.

CRAWFORD AJ, FALLON TJ \& GREEN DH. 1989. Classification and tectonic settings of boninites. In: CRAWFORD AJ (Ed.). Boninites and related rocks. Unwin Hyman Ltd. London, UK, 1-49.

DALZIEL IW. 1997. Neoproterozoic-Paleozoic geography and tectonics: review, hypothesis, environmental speculation. Geological Society of America Bulletin, 109(1): 16-42.

FOX PJ \& GALLO DG. 1984. A tectonic model for ridge-transform-ridge plate boundaries: implications for the structure of oceanic lithosphere. Tectonophysics, 104(3-4): 205-242.

FUKAO Y, MARUYAMA S, OBAYASHI M \& INOUE H. 1994. Geologic implication of the whole mantle P-wave tomography. Journal of the Geological Society of Japan, 100: 4-23.

GORINI MA. 1981. The tectonic fabric of the Equatorial Atlantic and adjoining continental margins: Gulf of Guinea to Northeastern Brazil. Série Projeto REMAC, 9, Petrobras, Rio de Janeiro, 11-117.

GUNG Y \& ROMANOWICZ B. 2004. Q tomography of the upper mantle using three component long period waveforms. Geophys. J. Int., 157: 813-830.

GURNIS M, MUELLER RD \& MORESI L. 1998. Cretaceous vertical motion of Australia and the Australian-Antarctic Discordance. Science, 279: 1499-1504.

HEKINIAN R, JUTEAU T, GRACIA E, UDINTSEV G, SICHLER B, SICHEL SE \& APPRIOUAL R. 2000. Submersible observations of Equatorial
Atlantic Mantle: The St. Paul Fracture Zone region. Marine Geophysical Research, 21: 529-560.

HEMOND C, LE FAOUDER A, BASSOULLET C, JUTEAU T \& SICHEL S. 2002. Evidence for recycled crustal material within the upper mantle beneath the St. Paul Fracture Zone, Equatorial Atlantic. EOS Trans. AGU, 83: F1448.

HORAN MF, WALKER RJ, MORGAN JW, GROSSMAN JN \& RUBIN AE. 2003. Highly siderophile elements in chondrites. Chemical Geology, 196: 5-20.

LASSITER JC \& HAURI EH. 1998. Osmium-isotope variations in Hawaiian lavas: evidence for recycled oceanic lithosphere in the Hawaiian plume. Earth Planet. Sci. Lett. 164: 483-496.

MARTIN CE. 1991. Osmium isotopic characteristics of mantle-derived rocks. Geochimica et Cosmochimica Acta, 55(5): 1421-1434.

MARUYAMA S. 1994. Plume tectonics. Journal of the Geological Society of Japan, 100: 24-49.

MEISEL T, WALKER RJ \& MORGAN JW. 1996. The osmium isotopic composition of the Earth's primitive upper mantle. Nature, 383: 517520.

MEISEL T, WALKER RJ, IRVING AJ \& LORAND JP. 2001. Osmium isotopic compositions of mantle xenoliths: a global perspective. Geochimica et Cosmochimica Acta, 65: 1311-1323.

MÉVEL C. 2003. Serpentinization of abyssal peridotites at mid-ocean ridges. C.R. Geoscience, 335: 825-852.

MOTOKI A, SICHEL SE, BAPTISTA NETO JA, SZATMARI P, MELLO SLM, SOARES R, MELO RC \& PETRAKIS GH. 2008. Características geomorfológicas do Arquipélago de São Pedro e São Paulo, Oceano Atlântico Equatorial, e sua relação com a história de soerguimento. Revista Brasileira de Geomorfologia. Manuscript submitted for publication.

MUTTONI G, KENT DV, GARZANTI E, BRACK P, ABRAHAMSEN N \& GAETANI M. 2003. Early Permian Pangea 'B' to Late Permian Pangea 'A'. Earth and Planetary Science Letters, 215(3-4): 379-394.

OHARA Y, YOSHIDA T, KATO Y \& KASUGA S. 2001. Giant megamullion in the Parece Vela backarc basin. Marine Geophysical Research, 22: 47-61.

RITSEMA J \& VAN HEIJST HJ. 2000. Seismic imaging of structural heterogeneity in Earth's mantle: evidence for large-scale mantle flow. Sci. Progr., 83: 243-259.

RITZWOLLER MH, SHAPIRO NM \& LEAHY GM. 2003. A resolved mantle anomaly as the cause of the Australian-Antarctic Discordance. J. Geophys. Res., 108(B12): 2559.

ROMANOWICZ B \& GUNG Y. 2002. Superplumes from the core-mantle boundary to the lithosphere. Science, 296: 513-516. 
ROY-BARMAN M \& ALLÈGRE CJ. 1994. ${ }^{187}$ Os/186 0 s ratios of midocean ridge basalts and abyssal peridotites. Geochimica et Cosmochimica Acta, 58(22): 5043-5054.

ROY-BARMAN M, WASSERBURG GJ, PAPANASTASSIOU DA \& CHAUSSIDON M. 1998. Osmium isotopic compositions and Re-Os concentrations in sulfide globules from basaltic glasses. Earth and Planetary Science Letters, 154(1-4): 331-347.

SCHILLING JG, RUPPEL C, DAVIS AN, MCCULLY B, TIGHE SA, KINGSLEY RH \& LIN J. 1995. Thermal structure of the mantle beneath the equatorial Mid-Atlantic Ridge: Inferences from the spatial variation of dredged basalt glass compositions. Journal of Geophysical Research, 100(B6): 10057-10076.

SCOTESE CR. 2004. The PALEOMAP Project. Available at: $<$ http://www.scotese.com>. Access on: December 15, 2007.

SHIREY SB \& WALKER RJ. 1998. The Re-Os isotope system in cosmochemistry and high-temperature geochemistry. Annual Review of Earth and Planetary Sciences, 26: 423-500.

SICHEL SE. 1990. Petrology and Geochemistry of the South Atlantic Ridge and Geochemical variation along the Cameroon Volcanic Line - Graduate School of Oceanography, University of Rhode Island-USA. Ph.D. thesis, $537 \mathrm{p}$.

SMITH WH \& SANDWELL DT. 1997. Global sea floor topography from satellite altimetry and ship depth soundings. Science Magazine, 277(5334): 1957-1962.

SNOW JE \& DICK HBJ. 1995. Pervasive magnesium loss by marine weathering of peridotites. Geochim. Cosmochim. Acta, 59: 4219-4235.
SNOW JE \& REISBERG L. 1995. Os isotopic systematics of the MORB mantle; results from altered abyssal peridotites. Earth and Planetary Science Letters, 133: 411-421.

STEINBERGER B. 2000. Slabs in the lower mantle - results of dynamic modelling compared with tomographic images and the geoid. Phys. Earth Planet. Inter., 118: 241-257.

TATSUMI Y \& MARUYAMA S. 1989. Boninites and high-Mg andesites: tectonics and petrogenesis. In: CRAWFORD AJ (Ed.). Boninites and related rocks. Unwin Hyman Ltd. London, UK, 50-71.

THIBAUD R, GENTE P \& MAIA M. 1998. A systematic analysis of the Mid-Atlantic Ridge morphology and gravity between $15^{\circ} \mathrm{N}$ and $40^{\circ} \mathrm{N}$ : constraints of the thermal structure. Journal of Geophysical Research, 103: 24223-24243.

THOMPSON G. 1981. St. Peter and St. Paul Rocks (Equatorial Atlantic) and the surrounding sea floor. Technical report for National Science Foundation, Grant OCE 77-26842 and OCE 80-24930. Wood Hole Oceanographic Institution, Massachusetts, USA. 35p. (unpublished).

TUCHOLKE BE, LIN J \& KLEINROCK MC. 1998. Megamullion and mullion structure defining oceanic metamorphic core complex on the MidAtlantic Ridge. Journal of Geophysical Research, 103: 9857-9866.

TUCHOLKE BE, FUJIOKA K, ISHIHARA T, HIRTH G \& KINOSHITA M. 2001. Submersible study of an oceanic megamullion in the central North Atlantic. Journal of Geophysical Research, 106: 16145-16161.

WALKER RJ, CARLSON RW, SHIREY SB \& BOYD FR. 1989. Os, Sr, Nd, and $\mathrm{Pb}$ isotope systematics of southern African peridotite xenoliths: implications for the chemical evolution of subcontinental mantle. Geochim. Cosmochim. Acta, 53: 1583-1595.

\section{NOTES ABOUT THE AUTHORS}

Susanna Eleonora Sichel. B.Sc. in Geology at Universidade Federal do Rio de Janeiro (UFRJ), Brazil, with an additional specialization at the University of ClausthalZellerfeld, Germany. M.Sc. in Geology at UFRJ and Ph.D. in Oceanography at the Graduate School of Oceanography of the University of Rhode Island, USA. Currently Professor in the Department of Geology of Universidade Federal Fluminense (LAGEMAR/UFF).

Sonia Esperança. B.A. in Geology at Rice University, M.Sc. in Earth Sciences at the Hebrew University of Jerusalem, and Ph.D. in Geology at Arizona State University. Held a number of faculty and staff appointments at Monash and Deakin Universities in Australia, and Old Dominion University and the University of Maryland-College Park in the United States. Currently manages the Petrology and Geochemistry program in the Division of Earth Sciences at the National Science Foundation, USA.

Akihisa Motoki. B.Sc. and M.Sc. in Geology at the Faculty of Science, Kobe University, Japan. Ph.D. in Geology at the Instituto de Geociências, Universidade de São Paulo, Brazil. Since 1983, has been Professor in the Department of Mineralogy and Petrology at the Universidade do Estado do Rio de Janeiro.

Marcia Maia. B.Sc. in Oceanography at the Universidade do Estado do Rio de Janeiro, Doctorate in Sciences in Geophysics at the Université de Paris XI, Orsay, and the Habilitation à Diriger des Recherches from the Université de Bretagne Occidentale. Currently, is research faculty in the CNRS - Institut Universitaire Européen de la Mer, Université de Bretagne Occidentale, Plouzané, France.

Mary F. Horan. B.A. in Geology at Rice University, Houston, Texas, USA and M.Sc. in Geochemistry at the State University of New York at Stony Brook. Employed as the Geochemistry Laboratory Manager in the Department of Terrestrial Magnetism of the Carnegie Institution of Washington, Washington DC, USA. 
Peter Szatmari. M.Sc. (Diplomarbeit) in Geology at the Eotvos University in Budapest, Hungary, and Ph.D. at the Grant Institute of Geology at the University of Edinburgh, U.K. Worked in the U.S. at the International Salt company, Princeton University and as an independent consultant. Worked as consultant and geologist for Petrobras since 1973.

Eliane da Costa Alves. B.Sc. in Geology at Universidade Federal do Rio de Janeiro, M.Sc. at Universidade Federal do Rio Grande do Sul, and Ph.D. in Geology and Geophysics at Universidade Federal do Rio de Janeiro. Currently Professor in the Department of Geology/LAGEMAR of the Instituto de Geociências, Universidade Federal Fluminense.

Sidney Luiz Matos Mello. Graduated in Geology at Universidade Federal do Rio de Janeiro, Brazil. M.Sc. in Geology at Universidade Federal do Rio de Janeiro. Ph.D. in Marine Geology and Geophysics at the School of Earth Sciences of the University of Leeds, UK. Working as Professor in the Department of Geology, Universidade Federal Fluminense, Brazil. 